\title{
Live What You Teach \& Teach What You Live: Student Views on the Acceptability of Teachers' Value-Related Statements about Sustainability and Climate Change
}

\section{GREgOR TORKAR $^{1}$}

$\approx$ This paper presents the results of a survey among pre-service and inservice students of pre-school education and students of environmental sciences on the acceptability of value-laden statements made by their teachers on issues of sustainable development and climate change. Fifteen statements were provided, and students had to choose among the options "acceptable statement", "unacceptable statement" and »cannot decide«. The questionnaire was completed by 139 students from two universities in Slovenia. The results show that the students expect their teachers to promote the principles of sustainable development. The majority of students considered any teacher's statement that would cast doubt on the cause or the necessity to act against climate change to be unacceptable. Teacher's statements emphasising global issues that have, or could have, a direct impact on developed countries (e.g. climate change) received higher support than those global questions that more heavily impact underdeveloped or developing countries (e.g. poverty, child labour, access to natural resources). In the conclusion, it is emphasised that teachers should assist students in developing their own moral positions on complex issues such as sustainable development and climate change. Structured discussion techniques, such as a panel discussion, forum and debate, should be regularly and carefully implemented into lectures at the university level.

Keywords: Sustainable development, Climate change, University education, Environmental education, Teaching, Values

1 University of Ljubljana, Faculty of Education, Kardeljeva ploščad 16, 1000 Ljubljana, Slovenia, and University of Nova Gorica, Laboratory for Environmental Research, Vipavska 13, 50oo Nova Gorica, Slovenia torkar.gregor@pef.uni-lj.si 


\section{Živi tisto, kar poučuješ, in poučuj tisto, kar živišs: pogledi študentov na sprejemljivost učiteljevih vrednotno orientiranih izjav o trajnosti in podnebnih spremembah}

\section{Gregor TORKAR}

$\propto$ V članku so predstavljeni izsledki raziskave med študenti predšolske vzgoje in študenti okoljskih znanosti o njihovih pogledih na sprejemljivost učiteljevih vrednotno orientiranih izjav o trajnostnem razvoju in podnebnih spremembah. Študentje so se opredelili do petnajstih podanih izjav. Pri tem so lahko izbirali med odgovori »sprejemljiva izjava«, »nesprejemljiva izjava« in »neodločen/-a«. Vprašalnik je izpolnilo 139 študentov iz dveh slovenskih univerz. V izsledkih ugotavljamo, da študentje od svojih profesorjev pričakujejo, da spodbujajo in podpirajo trajnostni razvoj. Večina vprašanih študentov tudi ne odobrava, da bi ti podvomili o vzrokih in nujnosti ukrepanja zoper podnebne spremembe. Podpora tistim izjavam, ki poudarjajo globalna vprašanja, ki imajo ali bi lahko imela neposreden vpliv na razvite države (npr. podnebne spremembe), je bila pri študentih večja kot podpora izjavam o globalnih vprašanjih, ki bolj prizadenejo nerazvite in razvijajoče se države (npr. revščina, otroško delo, dostop do naravnih virov). V sklepnem delu je poudarjena vloga učiteljev, ki morajo pomagati učečim pri razvijanju lastnih moralnih pogledov na kompleksna vprašanja, kot so trajnostni razvoj in podnebne spremembe. Strukturirane tehnike diskusije, kot so okrogla miza, forum in razprava, morajo biti na univerzitetni ravni zato redno in ustrezno implementirane.

Ključne besede: trajnostni razvoj, podnebne spremembe, univerzitetno izobraževanje, okoljsko izobraževanje, poučevanje, vrednote 


\section{Introduction}

In recent centuries, humanity has benefited from development that has enriched our lives, but also caused unprecedented environmental change. The Earth Summit in Rio de Janeiro (1992) challenged humanity to reduce its impact on the Earth. The assembled leaders adopted Agenda 21 for achieving sustainable development. Agenda 21 addresses the pressing environment and developmental problems and also aimed at preparing the world for future challenges in order to attain the long-term goals of sustainable development. The preamble to Agenda 21 commences with the following statement:

Humanity stands at a defining moment in history. We are confronted with a perpetuation of disparities between and within nations, a worsening of poverty, hunger, ill health and illiteracy, and the continuing deterioration of the ecosystems on which we depend for our well-being. However, integration of environment and development concerns and greater attention to them will lead to the fulfilment of basic needs, improved living standards for all, better protected and managed ecosystems and a safer, more prosperous future. No nation can achieve this on its own; but together we can - in a global partnership for sustainable development. (Agenda 21, 1992)

In principle, there is an agreement that social and economic development must be ecologically viable at present and in the long term, and that this is the task of the global community. However, when it comes to specific national and international policies and real actions in order to enable more sustainable living, agreements and initiatives (for example Agenda 21), it often breaks down. This is because such policies often hurt personal or group interests and values, leading to normative conflicts (Mulder, 2010).

Modern environmental scientists have the ability to foresee the future, but they are also often cursed in that no one believes them (Clayton \& Myers, 2009). One of the greatest challenges is to make scientific understandings and public (political) perceptions consistent. Many advocates of sustainable development recognise that a transition to global sustainability will require changes in human values, attitudes and behaviours (e.g. Raskin et al., 2002). Values are often invoked in discussions on how to develop a more sustainable relationship with the environment. Values are general preferences for ways of acting and underline more specific attitudes, preferences and behaviours (Dietz, Fitzgerald, \& Shwom, 2005). 
A considerable number of studies concerning values in environmental research are based on Schwartz's Value Theory (Schwartz, 1992). Schwartz defined a value as "a desirable trans-situational goal varying in importance, which serves as a guiding principle in the life of a person or other social entity « (Schwartz, 1992, p. 21). Values provide an efficient instrument for describing and explaining similarities and differences between persons, groups, nations, and cultures (Rokeach, 1973). The importance of these values may differ across persons and cultures, but the structure of these values is believed to be universal (Schwartz, 1992). Results from multinational studies supported the notion that values underlie environmental concerns and environmental worldviews (Schultz \& Zelezny, 1999). The values of self-transcendence tend to be positively correlated with measures of biospheric environmental concerns and negatively with egoistic environmental concerns, whereas values for self-enhancement tend to correlate negatively with biospheric concerns and positively with egoistic concerns (Schultz \& Zelezny, 1999). Strong support for the cross-cultural generalisability of the relationship between values and environmental attitudes and on the structure of environmental concern was reported (Schultz et al., 2005). Their analyses of the relationship between values and environmental behaviour show evidence of a positive relationship with self-transcendence values.

Environmental education, formal and informal, has the potential to affect a wide range of individuals and provides an opportunity to promote human-environmental harmony; it focuses on people's abilities to increase their understanding over the long run, affecting their attitudes, behaviour and worldviews in general (Clayton \& Myers, 2009). Formal school systems, from the pre-kindergarten to the graduate level, employ a wide range of methods, for example traditional courses, field trips, supplementary materials and community investigations (Volk \& MacBeth, 1998). Also relevant are informal environmental education settings, for example zoos, camps, park interpretative programmes, outdoor learning, citizen science projects, professional development, industry-based learning, etc. (Clayton \& Myers, 2009). Informal environmental education has a less structured curricula and could be more characterised as »free choice learning «. This means individuals voluntary use information given or displayed (e.g. leaflets, posters, web pages, magazines, books, movies, radio, television, etc.) (Clayton \& Myers, 2009). Wals (2007) described this as a shift in emphasis from education to social learning, where people form and exchange ideas through many types of social interaction.

Success of environmental education also depends on the psychological processes and readiness of those being educated (Clayton \& Myers, 2009) and 
educators (Torkar, 2010). Clayton and Myers (2009) particularly emphasised the importance of cognitive development and environmental knowledge (with special attention to knowledge of biology and ecology), affective and motivational factors (especially connection to nature and feelings about the self's ability to achieve effects in the world), and actual behaviour (participating, taking action and problem-solving).

\section{Research problem and research questions}

"Live what you teach \& teach what you live« is a principle in life that should be applied to many fields, including environmental education. This implies that people should behave in accordance with the values they teach. Korfiatis (2005) wrote that no science teaching can avoid communicating messages about how we humans look upon and treat nature. This statement is even more valid in the field of environmental education and education for sustainable development, where complex global problems, for example climate change, are confronted. The foundation that environmental education stands on is the position that knowledge is socially constructed, that there are cognitive, economic, moral and philosophical aspects to be considered and that there are no certainties in either theory or practice (Selby, 2007).

In 1975, an international United Nations Educational, Scientific, and Cultural Organisation (UNESCO) workshop in Belgrade produced a statement on environmental education aims, which still defines the mainstream in the field (Clayton \& Myers, 2009, p. 3):

The goal of environmental education is to develop a world population that is aware of, and concerned about, the environment and its associated problems, and which has the knowledge, skills, attitudes, motivations, and commitment to work individually and collectively toward solutions to current problems and prevention of new ones.

If environmental education is meant to help children learn and care for the environment, then those responsible for this (e.g. teachers) must know the types of learning experiences that help produce active and informed minds (Palmer \& Neal, 1994). Teachers are, or should be aware, of social pressures on them to act as model citizens and that their actions help establish the next generation's moral compass (Jacobson, McDuff, \& Monroe, 2006).

The main aim of the present study was to identify teachers' value-laden statements about sustainable development and climate change that are (not) acceptable for students. There is little known about students' acceptability of 
teachers' value-laden statements about environmental issues. Mulder (2010) explored the acceptability of value-laden statements among sustainable development teachers in engineering, engineers and engineering students. Sustainable development teachers in engineering were more critical about the valueladen statements than their students and professional engineers. He concluded that »teachers should help students identifying normative issues in work that seems to be of a technical nature and should help students in building up their own argument in these cases« (p. 83). This requires active learning processes or practice (Mulder, 2010). The teacher who wishes to be a successful environmental educator should become an example of a sustainable life style and not just preach about it. Dewey (1997) stated that an example is more potent than a principle, and a teacher's best conscious efforts may be more than counteracted by the influence of personal traits that he or she is unaware of or considers unimportant. Torkar (2009) discovered that teacher's attitudes and behaviours towards the environment and nature protection were influenced by values expressing universalism, moral norms, personal and spiritual growth, and selftranscendence. Kollmuss and Agyeman (2002) reported that people often profess positive environmental attitudes but do not engage in corresponding behaviour. This inconsistency was confirmed in a previously mentioned study by Torkar (2009). In the school environment, teachers are closely observed by students; therefore, a teacher's strong moral position must be an implicit part of the knowledge the teacher wants children to absorb (Krasko, 2004).

Two groups of students with different levels of scientific knowledge concerning environmental issues were questioned in order to determine if their environmental knowledge influenced the acceptability of a teacher's value-laden statements. It is also necessary to know how students' disagreements with statements are discussed in the classroom. Therefore, students' willingness to express their disagreement with the teacher's value-laden statements in the classroom was investigated.

\section{Method}

\section{Participants}

The survey was carried out in fall 2010, winter 2010-11 and fall 2012. A questionnaire was completed by 139 respondents from two universities in Slovenia: 49 students of environmental sciences (SES) in their last year of study ( $5^{\text {th }}$ Semester) and 90 pre-school education students (SPE) in their second year of study ( $3^{\text {rd }}$ Semester). More details concerning the sample are presented in Table 1. 
Table 1. Sample details

\begin{tabular}{|l|l|c|c|}
\hline \multicolumn{2}{|c|}{} & SES & SPE \\
\hline \multirow{3}{*}{ Gender } & Male & 8 & 1 \\
\cline { 2 - 4 } & Female & 41 & 89 \\
\hline \multirow{4}{*}{ Age } & Average & 22.6 & 27.3 \\
\cline { 2 - 4 } & Min. & 20 & 20 \\
\cline { 2 - 4 } & Max. & 31 & 50 \\
\hline
\end{tabular}

\section{Research design}

Participating students from pre-school education completed the questionnaire before a biology course session at Faculty of Education University of Ljubljana. They were in their second year of a three-year study programme. Participating students from environmental sciences were in their final (third) year of the study programme in the Faculty of Environmental Sciences University of Nova Gorica. They completed the questionnaires before a nature conservation course session.

The questionnaire consisted of 15 value-laden statements focused on three main dimensions: (1) ecological, social and economic dimensions of sustainable development, (2) developed-developing countries, and (3) climate change. Some questions were taken from the questionnaire developed by Mulder (2010). For each given value-laden statement students had to choose among options "acceptable statement «, »unacceptable statement « and "cannot decide«. Students were also asked how they reacted to unacceptable statements from their teachers. Students needed 10 minutes on average to answer the questions.

Descriptive analysis of the results was conducted. The differences between groups of students were tested with a $\chi^{2}$ test. We also compared students' views on the acceptability of value-laden statements and their respond when hearing them (Figure 1).

\section{Results}

The acceptability of 15 value-laden statements about sustainable development (SD) and climate change (CC) made by teachers was evaluated by students of pre-school education (SPE) and of environmental sciences (SES). The results for the two groups of students are presented separately and in total. The results in Table 2 show that students expect their teachers to promote the principles of sustainable development and to behave in accordance with what 
they teach. Seven out of ten students found any family planning policy that would control number of births and stabilise the population on the planet to be unacceptable. Less than two thirds of the respondents accepted a teacher's statements supporting global equity of access to natural resources, the responsibility of developed countries to promote sustainable development and the eradication of poverty in underdeveloped and developing countries. Half of the students found the statement that calls for opposition toward government that will not lead us to sustainable development to be unacceptable. Only three out of five students support their teachers' statements that child labour is unacceptable in all countries of the world.

However, the majority of students considered any teacher's statement that would throw doubt about the cause or necessity to act against climate change to be unacceptable (Table 3). For example, students found unacceptable a teacher's statement that would consider climate change in a positive way, just because some areas could, as a result, have a warmer climate and lower bills for heating. Students also found to be unacceptable the statement that humans are not a cause of climate change; therefore, there is no need for action.

Both groups of students found teacher's carelessness about sustainable development or climate change to be highly unacceptable.

However, there are only two statistically significant differences between groups. Students of environmental sciences were more supportive of the statement that calls for opposition toward governments that do not support sustainable development $\left(\chi_{2}=15.317, p=0.000\right)$. Another significant difference between the groups of students was their view on the acceptability of the statement that was supporting new family planning programs that would regulate the human population on the planet $\left(\chi^{2}=10.179, p=0.006\right)$. Students from preschool education found this teacher's statement more unacceptable, while students of environmental sciences expressed a more neutral position towards the statement. 
Table 2. Value-laden statements made by teachers on issues of sustainable development (SD) and their acceptability for students of environmental sciences (SES) and pre-school education (SPE).

\begin{tabular}{|c|c|c|c|c|c|c|c|}
\hline \multirow{2}{*}{ Teacher's statement } & \multirow{2}{*}{ Sample } & \multicolumn{2}{|c|}{ Acceptable } & \multicolumn{2}{|c|}{ Unacceptable } & \multicolumn{2}{|c|}{ Neutral } \\
\hline & & $f$ & $f \%$ & $f$ & $f \%$ & $f$ & $f \%$ \\
\hline \multirow{3}{*}{$\begin{array}{l}\text { 1. I do not care about SD; I just } \\
\text { make a living teaching it! }\end{array}$} & SES & 2 & 4.1 & 45 & 91.8 & 2 & 4.1 \\
\hline & SPE & 7 & 7.8 & 76 & 84.4 & 7 & 7.8 \\
\hline & Total & 9 & 6.5 & 121 & 87.1 & 9 & 6.5 \\
\hline \multirow{3}{*}{$\begin{array}{l}\text { 2. We have to fight against a } \\
\text { government that does not } \\
\text { support SD. }\end{array}$} & SES & 20 & 40.8 & 23 & 46.9 & 6 & 12.2 \\
\hline & SPE & 12 & 13.3 & 49 & 54.4 & 29 & 32.2 \\
\hline & Total & 32 & 23.0 & 72 & 51.8 & 35 & 25.2 \\
\hline \multirow{3}{*}{$\begin{array}{l}\text { 3. Child labour is intolerable in } \\
\text { all countries of the world. }\end{array}$} & SES & 33 & 70.2 & 11 & 23.4 & 3 & 6.4 \\
\hline & SPE & 52 & 57.8 & 31 & 34.4 & 7 & 7.8 \\
\hline & Total & 85 & 62.0 & 42 & 30.7 & 10 & 7.3 \\
\hline \multirow{3}{*}{$\begin{array}{l}\text { 4. Developed countries should } \\
\text { be responsible for eradication } \\
\text { of poverty in underdeveloped } \\
\text { and developing countries. }\end{array}$} & SES & 26 & 53.1 & 7 & 14.3 & 16 & 32.7 \\
\hline & SPE & 63 & 70.0 & 11 & 12.2 & 16 & 17.8 \\
\hline & Total & 89 & 64.0 & 18 & 12.9 & 32 & 23.0 \\
\hline \multirow{3}{*}{$\begin{array}{l}\text { 5. SD means stabilisation of } \\
\text { population numbers; there- } \\
\text { fore, we need family planning } \\
\text { programs. }\end{array}$} & SES & 7 & 14.3 & 27 & 55.1 & 15 & 30.6 \\
\hline & SPE & 3 & 3.3 & 71 & 78.9 & 16 & 17.8 \\
\hline & Total & 10 & 7.2 & 98 & 70.5 & 31 & 22.3 \\
\hline \multirow{3}{*}{$\begin{array}{l}\text { 6. Developed countries have a } \\
\text { responsibility to support SD } \\
\text { in developing countries. }\end{array}$} & SES & 26 & 53.1 & 9 & 18.4 & 14 & 28.6 \\
\hline & SPE & 56 & 62.2 & 11 & 12.2 & 23 & 25.6 \\
\hline & Total & 82 & 59.0 & 20 & 14.4 & 37 & 26.6 \\
\hline \multirow{3}{*}{$\begin{array}{l}\text { 7. Developed countries should } \\
\text { do more to close their bor- } \\
\text { ders to economic migrants } \\
\text { from Africa and Asia. }\end{array}$} & SES & 6 & 12.2 & 32 & 65.3 & 11 & 22.4 \\
\hline & SPE & 7 & 7.8 & 61 & 67.8 & 22 & 24.4 \\
\hline & Total & 13 & 9.4 & 93 & 66.9 & 33 & 23.7 \\
\hline \multirow{3}{*}{$\begin{array}{l}\text { 8. Everybody should become a } \\
\text { vegetarian. }\end{array}$} & SES & 2 & 4.1 & 41 & 83.7 & 6 & 12.2 \\
\hline & SPE & 1 & 1.1 & 81 & 90.0 & 8 & 8.9 \\
\hline & Total & 3 & 2.2 & 122 & 87.8 & 14 & 10.1 \\
\hline \multirow{3}{*}{$\begin{array}{l}\text { 9. There is nothing wrong with } \\
\text { killing whales. }\end{array}$} & SES & 2 & 4.2 & 44 & 91.7 & 2 & 4.2 \\
\hline & SPE & 0 & 0.0 & 87 & 96.7 & 3 & 3.3 \\
\hline & Total & 2 & 1.4 & 131 & 94.9 & 5 & 3.6 \\
\hline \multirow{3}{*}{$\begin{array}{l}\text { 10. All people on the planet } \\
\text { should have equal rights to } \\
\text { access natural resources, like } \\
\text { oil and natural gas. }\end{array}$} & SES & 31 & 64.6 & 3 & 6.3 & 14 & 29.2 \\
\hline & SPE & 52 & 57.8 & 18 & 20.0 & 20 & 22.2 \\
\hline & Total & 83 & 60.1 & 21 & 15.2 & 34 & 24.6 \\
\hline \multirow{3}{*}{$\begin{array}{l}\text { 11. As long my teaching salary } \\
\text { is so low, I am not going to } \\
\text { advocate SD. }\end{array}$} & SES & 0 & 0.0 & 47 & 95.9 & 2 & 4.1 \\
\hline & SPE & 3 & 3.3 & 85 & 94.4 & 2 & 2.2 \\
\hline & Total & 3 & 2.2 & 132 & 95.0 & 4 & 2.9 \\
\hline
\end{tabular}


Table 3. Value-laden statements made by teachers on issues of climate change (CC) and their acceptability for students of environmental sciences (SES) and pre-school education (SPE).

\begin{tabular}{|c|c|c|c|c|c|c|c|}
\hline \multirow{2}{*}{ Teacher's statement } & \multirow{2}{*}{ Sample } & \multicolumn{2}{|c|}{ Acceptable } & \multicolumn{2}{|c|}{ Unacceptable } & \multicolumn{2}{|c|}{ Neutral } \\
\hline & & $f$ & $\mathrm{f} \%$ & $f$ & $f \%$ & $f$ & $f \%$ \\
\hline \multirow{3}{*}{$\begin{array}{l}\text { 12. } \mathrm{CC} \text { is not caused by humans, } \\
\text { so we need not reduce } \mathrm{CO} 2 \\
\text { emissions. }\end{array}$} & SES & 3 & 6.3 & 41 & 85.4 & 4 & 8.3 \\
\hline & SPE & 0 & 0.0 & 84 & 93.3 & 6 & 6.7 \\
\hline & Total & 3 & 2.2 & 125 & 90.6 & 10 & 7.2 \\
\hline \multirow{3}{*}{$\begin{array}{l}\text { 13. CC is positive, because it } \\
\text { brings to some areas of the } \\
\text { world a warmer climate and } \\
\text { lower bills for the heating. }\end{array}$} & SES & 1 & 2.0 & 45 & 91.8 & 3 & 6.1 \\
\hline & SPE & 2 & 2.2 & 79 & 87.8 & 9 & 10.0 \\
\hline & Total & 3 & 2.2 & 124 & 89.2 & 12 & 8.6 \\
\hline \multirow{3}{*}{$\begin{array}{l}\text { 14. CC is punishment sent from } \\
\text { God and we must now pay } \\
\text { for our sins. }\end{array}$} & SES & 0 & 0.0 & 49 & 100.0 & 0 & 0.0 \\
\hline & SPE & 2 & 2.2 & 83 & 92.2 & 5 & 5.6 \\
\hline & Total & 2 & 1.4 & 132 & 95.0 & 5 & 3.6 \\
\hline \multirow{3}{*}{$\begin{array}{l}\text { 15. CC was made up by those } \\
\text { who want to sell us expensive } \\
\text { eco-products. }\end{array}$} & SES & 2 & 0.9 & 44 & 19.2 & 3 & 1.3 \\
\hline & SPE & 2 & 2.2 & 77 & 85.6 & 11 & 12.2 \\
\hline & & 4 & 2.9 & 121 & 87.1 & 14 & 10.1 \\
\hline
\end{tabular}

Finally, students were asked to describe how they would most probably react to unacceptable value-laden statements made by their teacher (Figure 1).

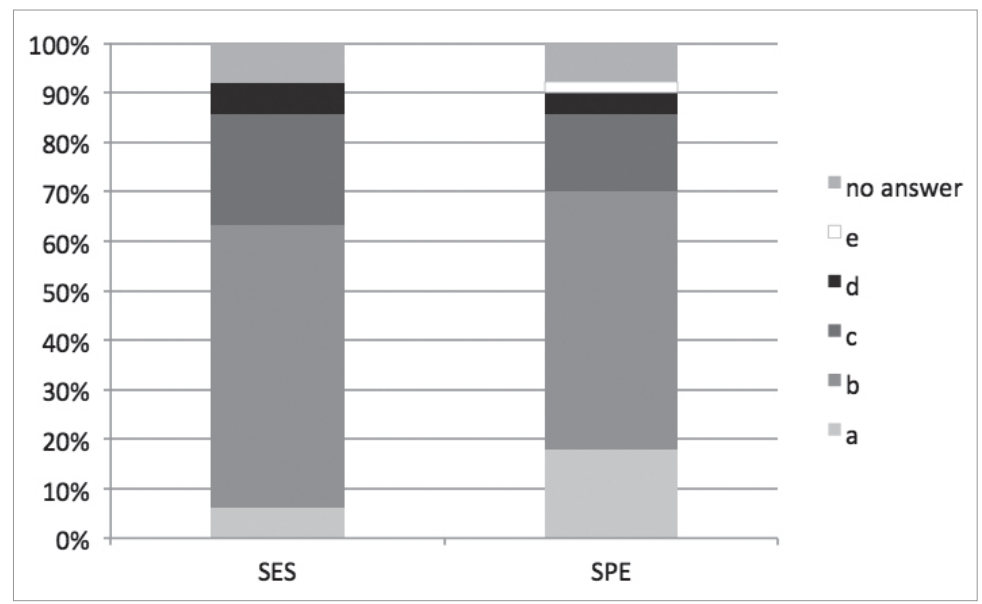

Legend: $\mathrm{a}$ - I remain quiet, $\mathrm{b}$ - I become alert and mention my concerns to colleague(s), c - I publicly express my disagreement and discuss it in the classroom, $\mathrm{d}$ - I privately discuss my concerns with the teacher, e - I have not yet heard any unacceptable statements until now.

Figure 1. Student's reaction to unacceptable value-laden statements made by their teachers. 
Most of the students would become alert and discuss the statement with colleague(s) in the classroom. Students from environmental sciences were more willing to express their disagreement with the teacher's statement and discuss it in the classroom or in private conversation with the teacher. Only two students had not yet heard any unacceptable statements.

\section{Discussion and conclusion}

The first and most important aim of the study was to investigate students' views on the acceptability of academics' value-related statements about sustainability and climate change. Overall, students found carelessness on the part of teacher regarding sustainable development or climate change to be highly unacceptable. The results show that students expect their teachers to promote the principles of sustainable development, which confirms the findings of other researchers (e.g. Jacobson et al., 2006; Mulder, 2010). It appears that statements emphasising global issues that have, or could have, a direct impact on developed countries (e.g. climate change) received higher support than those global questions that have greater impact on underdeveloped or developing countries (e.g. poverty, child labour, access to natural resources). This opens an important question about the personal or group interests and values that could harm global agreements and initiatives, for example Agenda 21. Humanity is facing some global environmental challenges that require some self-limiting of (regional) group interests that could have a negative effect on the standard of living in underprivileged communities.

Views on the acceptability of academics' value-related statements were investigated in two groups of students with different levels of knowledge about sustainable development and climate change topics. Many studies of knowledge and attitudes have found a significant relationship between the two variables (e.g. Olson, Bowman, \& Roth, 1984; Prokop, Kubiatko, \& Fančovičova, 20o8; Torkar, Mohar, Gregorc, Nekrep, \& Hönigsfeld Adamič, 2010). The aim was to discover whether the level of knowledge influenced the acceptability of a teacher's value-laden statements. In only two out of 15 statements were significant differences between groups found. Students of preschool education, with a lower level of environmental knowledge, found the statement that was supporting new family planning programs, which would stabilise the world population, more unacceptable; while students of environmental sciences were more supportive of the statement that calls for opposition toward government that does not support sustainable development. This also indicates a slightly higher level of activism and/or pro-active behaviour, among students of environmental 
sciences, which was also noticed from the results presented in Figure 1 where a high degree of passivity or lack of confidence among students was noticed. Two thirds of the respondents would not express their disagreement with teacher's value-laden statements or discuss it with their teacher.

The complexity of sustainable development is well acknowledged. The more complex a subject is to learn, the less potential there is for students to achieve mastery of it through passive learning approaches (von Blottnitz, 2006). Mulder (2010) was convinced that the basic university teaching practice of the all-knowing lecturer who transmits one clear message to students is often perceived as preaching. He believes that it is far more useful to create confusion, because in this situation students are forced to think. Therefore, it is of great importance that teachers at all levels of education, particularly at universities, encourage students to clarify the moral dimension involved in issues of sustainability, and assist them in developing their own moral positions on such complex issues.

Of course, it is not sufficient merely to increase the frequency of verbal encouragements to participate in discussions. It is necessary to adjust the entire programme and curriculum, including goals for the subjects. More emphasis should be devoted to the development of skills, such as critical thinking and collaborative research, where information, ideas and opinions are shared. Structured discussion techniques, such as panel discussions, forums and debates, should be regularly and carefully implemented into lectures. Discussions can also be the main mode of learning. Well-run discussions can also help participants learn communication skills in the group and broaden their perspective. As it was emphasised in the introduction of this paper, environmental education stands on the position that knowledge is socially constructed, that there are no certainties in theory or in practice (Selby, 2007). Structured discussions should be essential techniques of educational experience. This can help us build a global partnership for sustainable development (Agenda 21, 1992).

\section{References}

Agenda 21, United Nations (1992). Retrieved May 92012 from: http://www.un.org/esa/dsd/agenda21 Clayton, S., \& Myers, G. (2009). Conservation Psychology: understanding and promoting human care for nature. Chichester: Wiley-Blackwell.

Dewey, J. (1997). How we think. Boston: DC Heath \& Co. New York: Dover Publications Inc.

Dietz, T., Fitzgerald, A., \& Shwom, R. (2005). Environmental values. Annual Review of Environmental Resources, 30, 335-372.

Jacobson, S. K., McDuff, M. D., \& Monroe, M. C. (2006). Conservation education and outreach 
techniques. New York: Oxford University Press, Inc.

Karp, D. G. (1996). Values and their effect on pro-environmental behavior. Environment and Behaviour, 28(1), 111-133.

Kollmuss, A., \& Agyeman, J. (2002). Mind the gap: why do people act environmentally and what are the barriers to pro-environmental behaviour? Environmental Education Research, 8(3), 239-260.

Korfiatis, K. J. (2005). Environmental education and the science of ecology: exploration of an uneasy relationship. Environmental Education Research, 11(2), 235-248.

Krasko, G. L. (2004). This Unbearable Boredom of Being: A crisis of meaning in America. New York: iUniverse.

Mulder, K. F. (2010). Don't preach. Practice! Value laden statements in academic sustainability education. International Journal of Sustainability in Higher Education, 11(1), 74-85.

Nordlund, A. M., \& Garvill, J. (2002). Value structures behind pro-environmental behavior. Environment and Behavior, 34(6), 740-756.

Olson, E. C., Bowman, M., \& Roth, R. (1984). Interpretation and non-formal environmental education in natural resources management. Journal of Environmental Education, 15(4), 6-10. Palmer, J. (1995). Influences of pro-environmental practices. In J. Palmer, W. Goldstein, \& A. Curnow (Eds.), Planning education to care for the earth (pp. 3-8). Gland, Switzerland \& Cambridge: IUCN. Palmer, J., \& Neal, P. (1994). The Handbook of Environmental Education. London: Routledge. Raskin, P., Banuri, T., Gallopín, G., Gutman, P., Hammond, A. et al. (2002). Great Transition: The Promise and Lure of the Times Ahead. Boston: Stockholm Environment Institute.

Rokeach, M. (1973). The Nature of Human Values. New York: Free Press.

Prokop, P., Kubiatko, M., \& Fančovičová, J. (2008). Slovakian Pupils’ Knowledge of, and Attitudes toward, Birds. Anthrozoös, 21(3), 221-235.

Schultz, P. W., Gouveia, V. V., Cameron, D. L., Tankha, G., Schmuck, P., \& Franek, M. (2005). Values and their relationship to environmental concern and conservation behavior. Journal of Cross-Cultural Psychology, 36(4), 457-475.

Schultz, P. W., \& Zelezny, L. (1999). Values as predictors of environmental attitudes: evidence for consistency across 14 countries. Journal of Environmental Psychology, 19(3), 255-265.

Schwartz, S. H. (1992). Universals in the content and structure of values: Theoretical advances and empirical tests in 20 countries. In M. P. Zanna (Ed.), Advances in Experimental Social Psychology (pp. 1-65). San Diego: Academic Press.

Selby, D. (2007). As the heating happens: Education for Sustainable Development or Education for Sustainable Contraction? International Journal of Innovation and Sustainable Development, 2(3-4), $249-267$.

Thøgersen, J., \& Ölander, F. (2002). Human values and the emergence of a sustainable consumption pattern: A panel study. Journal of Economic Psychology, 23, 605-630.

Torkar, G. (2009). Učiteljeve vrednote in njihov odnos do okolja in varstva narave [Teacher's values and relationship with environment and nature protection]. Didactica Slovenica-Pedagoška obzorja, 24(1), 97-108. 
Torkar, G. (2010). How to set a good example to pupils?: Teachers' purpose in life and behavioural intentions to protect nature. In S. Dolinšek (Ed.), XIV. IOSTE Socio-cultural and human values in science and technology education: proceedings. Symposium, International Organization for Science and Technology Education, June 13-18 2010, Bled, Slovenia. Ljubljana: Institute for Innovation and Development of University.

Torkar, G., Mohar, P., Gregorc, T., Nekrep, I., \& Hönigsfeld Adamič, M. (2010). The conservation knowledge and attitudes of teenagers in Slovenia toward the Eurasian Otter. International Journal of Environmental and Science Education, 5(3), 341-352.

Volk, T. L., \& MacBeth, B. (1998). Environmental literacy in the U.S.: What should be...what is...getting from here to there. Rock Springs, GA: North American Association for Environmental Education. von Blottnitz, H. (2006). Promoting active learning in sustainable development: experiences from a $4^{\text {th }}$ year chemical engineering course. Journal of Cleaner Production, 14(9-11), 916-923.

Wals, A. E. J. (2007). Social learning towards a more sustainable world. Principles, perspectives, and praxis. Wageningen: Wageningen Academic Publishers.

\section{Biographical note}

Gregor Torkar, PhD, is an assistant professor at the Faculty of Education, University of Ljubljana, where he teaches undergraduate courses in biological didactics and environmental education. He is also teaching nature conservation course at the Faculty of Environmental Sciences, University of Nova Gorica. He is involved in various international projects related to nature conservation and education for sustainable development. His main research interest focuses currently on understanding students' knowledge and attitudes toward various biological and environmental themes, and studying sustainable management of natural resources and services. He is steering group member and workgroup leader in PERL (The Partnership for Education and Research about Responsible Living), developing active methodology toolkits on education for sustainable lifestyles and production. 